\title{
SEDIMENT AND SUSPENDED PARTICULATE MATTER OF JAKARTA BAY, INDONESIA
}

\author{
Iwan G. Tejakusuma, Seno Adi, M.S. Nugrahadi, Rahmania D. and T. Yanagi \\ Pusat Pengelolaan Sumberdaya Lahan, Wilayah dan Mitigasi Bencana Deputi TPSA, BPPTeknologi \\ JI. MH. Thamrin No. 8 Jakarta Pusat
}

\begin{abstract}
Jakarta Bay is a semi enclosed bay located in the northern coast of Jakarta Metropolitan City. Hydrologically 13 rivers flowing in the Jakarta region and there are three big rivers with significant discharge to the Jakarta Bay namely Citarum, Ciliwung, and Cisadane Rivers. Jakarta, as Indonesian capital city with population of 8.725 .630 inhabitants, and another 15 million people live in the surrounded suburban of Jakarta, creates a significant anthropogenic impact to the environmental system. Limited infrastructures, such as no sewerage system and lack of industrial waste management, cause the rivers in this region have over their carrying capacity.

Seventeen sampling stations were determined in the Jakarta Bay, consisting of 5 stations at the river mouths (estuaries) and other 12 stations in the bay spreading from the coastal to offshore areas. Water and sediment samples were taken during 2 monsoonal or seasonal variations, August 2006 for dry season and February 2007 for rainy season respectively. Additionally, samples were also taken in May 2007.

Sediment distribution in the estuary consists mostly of black clay. The sediments clays were bad smell. In the coastal region and in the dry season, the sediments consists of black clay and at one sampling site (station S3) the sediment was bad smell. However, all sampling sites became bad smell in the rainy season. In the inner bay area, sediments were greyish green sandy clay with some shell fragments. In the outer bay, the sediments were dominated by greyish green clayey sand with some shell fragments. The black clay with bad smell is indicative of anthropogenic influence from Jakarta River Basin.

$\mathrm{C} / \mathrm{N}$ ratio of the sediments in the dry season ranged from 1 to about 4.2 where in the estuaries (at stations M1, M2 and M4) the ratio were higher compared to the inner and outer bays. The $\mathrm{C} / \mathrm{N}$ ratio of suspended particulate matter ranged from the lowest ratio of 0.7 to the highest ratio of 17.7 at the bottom layer and lesser ranged of 0.7 to 9.8 at surface layer. POC concentrations ranged between 50-650 $\mu \mathrm{M}$ and 50-900 $\mu \mathrm{M}$, in February and May, respectively. High concentrations of POC exists along the coastline or estuaries then decreasing toward the sea. POC is distributed widely in February than that in May due to higher discharge from the rivers. The average TOC concentrations in February is lower than that in May, but the TOC load in February was much higher than that in May due to the big differences of river discharge and because the samples were taken a week after the big flood in Jakarta area (February $4^{\text {th }}-6^{\text {th }}$, 2007). Total organic carbon fluxes from the river to the bay in February and May 2007 were 107.6 T/day C and $42.7 \mathrm{~T}$ /day $C$, respectively.
\end{abstract}

Key words : sediment, anthropogenic influence, C/N Ratio, POC, TOC, flux

\section{INTRODUCTION}

Jakarta, as Indonesian capital city with the population of 8.725 .630 (Wirahadikusumah, 2004) inhabitants and other 15 million people live in the surrounded suburban of Jakarta, has a strategic role of regional socio economic development. The urbanization in the greater Jakarta (called Jabodetabek) creates a significant anthropogenic impact to the environmental system. At the other hand, the limited infrastructures, such as no sewerage system and lack of industrial waste management, cause the rivers in this region have over their carrying capacity.

The urbanization in this region has changed the green area to the impervious area dramatically, so very limited forest and even tress exist in this area. Moreover it was reported in the year 2000 that a significant solid domestic waste could not be taken to the land fill system in the amount of $4428 \mathrm{~m}^{3}$ garbage per day, so part of it or surely much of it went to the river system. It was also reported that approximately $500 \mathrm{~m}^{3}$ garbage per day was evacuated from the river water gate during the rainy season (Kompas, 23 January 2005). Consequently, it is less carbon 
storage in the terrestrial system and more carbon transport to the river system. In order to know the characteristics and pattern and possible relationships to Jakarta land use changes, the sediment and suspended particulate matter in the Jakarta Bay were investigated.

\section{METHODS}

The methodology comprises field survey, laboratory analyses and data analyses. Sediment samples from Jakarta Bay were taken by a Grab sampler, and then stored in the plastic bottles. A systematic sampling station in the coastal waters were arranged based on bottom topography of approximately 5, 10, 20 and over 20 meter (m) depth. The sampling stations can be seen in figure 1 . The water and sediment samples were taken in the period of 2 monsoonal or seasonal variations (August and February) from the river mouth (estuary), the coastal and the bay. Sampling were done using speedboat. Seventeen sampling stations were determined at the Jakarta Bay, consists of 5 stations at the river mouths and another 12 stations from the coastal line toward offshore (see figure 1).

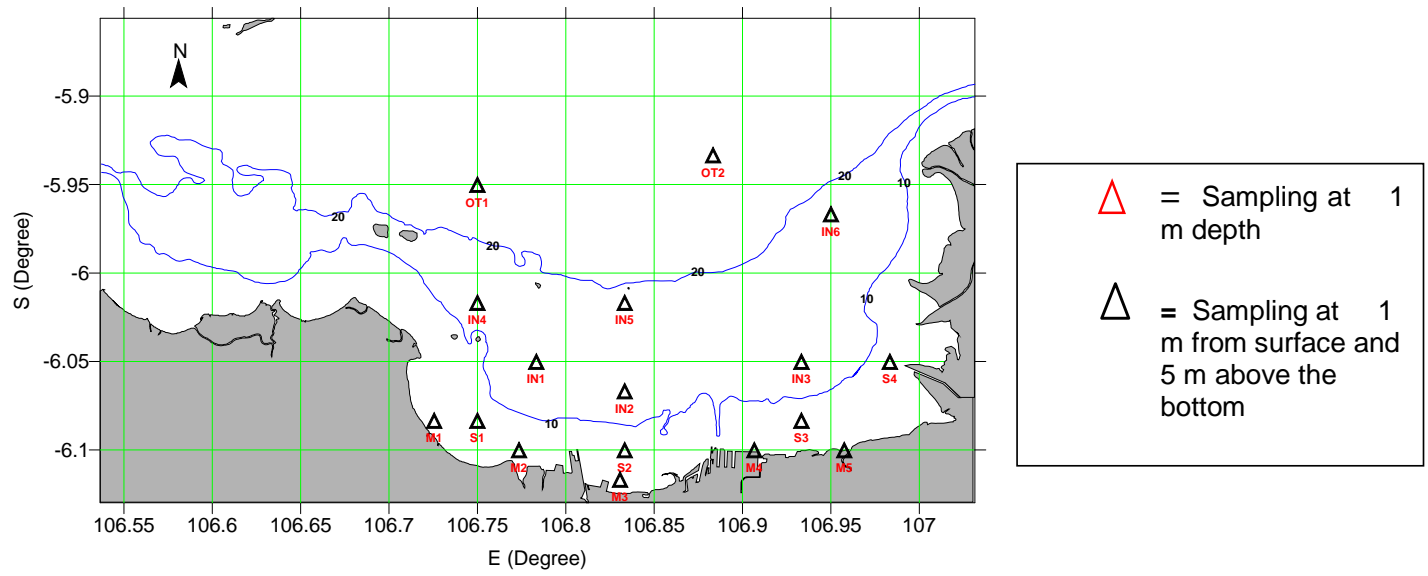

Figure 1. Sampling stations in the Jakarta Bay

A total of 50 samples (25 samples for each seasonal period) were taken, 10 samples from the rivers and 40 samples from the Jakarta Bay. For determination of particulate organic carbon (POC) samples were filtered through preweighed, pre-combusted glass fiber filters (Whatmann GF/F) and dried at 400 C. All samples were stored frozen in a cool box until further analysis.
Water samples were brought to Bogor Institute of Agriculture Laboratory and had been analyzed there for Total N, Total C, TSS and some parameters that were also measured with in situ probe, to be compared, such as TDS, conductivity, salinity and $\mathrm{pH}$. The methodologies for analysis can be seen in table 1 .

Table 1. Methodology for analysis

\begin{tabular}{|l|l|l|}
\hline No. & \multicolumn{1}{|c|}{ Parameters } & \multicolumn{1}{c|}{ Methods } \\
\hline 1 & Total Suspended Solid & APHA, 20 th $, 1998,2540-\mathrm{D} /$ Gravimetric \\
\hline 2 & Total Dissolved Solid & APHA, 20 \\
\hline
\end{tabular}

Samples for POC analysis purposes were brought to the Zentrum fur Marine Tropenokologie (ZMT) in Bremen, Germany. Particulate Organic Carbon, Total Nitrogen and Total Particulate Carbon were analyzed with Carlo Elba NA 2100 Elemental Analyzer. Detailed of the laboratory analysis for $\mathrm{DOC}$ and $\mathrm{POC}$ were explained in Baum et al (2007). GF/F filtered particulate samples from Jakarta Bay can be seen in figure 7,8 and 9.

\section{RESULTS}

\subsection{Jakarta Catchment Area}

The Jakarta catchments area consists of mainly agro forestry, bushes, irrigated rice fields, forests, cities - industrial estate and aquaculture. Villages, swamps, golf fields and dams can also be found in a smaller scale. Human urbanisation in the greater Jakarta city has resulted in significant land use changes. Furthermore, this 
condition has resulted in considerable stress on coastal environment. The effects include:

- Pollution in Jakarta Bay due to the domestic and industrial wastes brought by the rivers as well as port and shipping activities.

- The extraction of groundwater has resulted in land subsidence, seawater intrusion and damage to buildings.

- The sand mining in the coastal area has resulted in coastal abrasion and mining of coral sand, whether cutting of mangrove forests has increased the attacks of the waves.

- Dam constructions or storage lakes in the Citarum River strongly reduce the sediment transport down stream and adversely affecting the growth of Citarum delta.

- Data of land use changes showed that from 1990 to 1999 , the area of human settlement has increased from $7.3 \%$ to $22.94 \%$ and rice fields has decreased from $34.88 \%$ to $13.32 \%$ (Ministry of Environment, 2002).

Hydrologically, there are 13 rivers across the Jakarta region, of which 3 big rivers with significant discharge to the Jakarta bay, they are Citarum River, Ciliwung River, and Cisadane River. Citarum River has the biggest drainage area and the longest river length. However this river keeps the water discharge in the 3 cascade dams upstream to the middle part of the stream. This river flows to the eastern part of Jakarta Bay where not all of discharge goes to Jakarta Bay. The most significant river is Ciliwung river originating from the volcanic complex of Pangrango and Gede, this river cross the central part of Jakarta city and always causes heavy flood as well as heavy pollution. During the flood, the river discharge reported over $500 \mathrm{~m} 3 / \mathrm{s}$ and brought $11.000 \mathrm{~m} 3$ debris of trees and housing material. The other river is Cisadane river though shorter $(110 \mathrm{~km}$ long) but has medium river basin area (1100 km2) compare to other 2 rivers. The river spring originally from Salak Mount flow downstream to the western part of Jakarta Bay with the maximum discharge reported of 973 $\mathrm{m} 3 / \mathrm{s}$. Again this river does not flow all the discharge to the Jakarta Bay.

River pollutions showed by the Ciliwung River, which previously has been used as a source of raw water for water treatment plant. Average $\mathrm{COD}$ and $\mathrm{BOD}$ of the river show values of $28.42 \mathrm{mg} / \mathrm{l}$ and $17.83 \mathrm{mg} / \mathrm{l}$ respectively. These values exceed the standard values of raw water for the water treatment plant of Jakarta which is $10 \mathrm{mg} / \mathrm{l}$ for BOD and $20 \mathrm{mg} / \mathrm{l}$ for COD.

Seasonally, there are two monsoonal seasons at the Jakarta Bay, called as west monsoon that is related to the rainy season occurs in October to March, and the east monsoon that is related to the dry season occurs in April to September. The yearly rainfall amount is varied from $1800 \mathrm{~mm} /$ year in the coastal area to $4000 \mathrm{~mm} /$ year in the Bogor and mountainous area. This high yearly rainfall in the upstream of mountainous or highland region in the southern part of Greater Jakarta indicate higher rainfall intensity up to $80 \%$ in the rainfall season. Therefore the water and sediment flux in the river lead to the coastal water of Jakarta Bay would be much more transported significantly during this season.

Table 1. Characteristics of significant rivers flow to Jakarta Bay

\begin{tabular}{|c|c|c|c|c|c|c|}
\hline \multirow[t]{2}{*}{ No } & \multirow{2}{*}{$\begin{array}{l}\text { Name of } \\
\text { River }\end{array}$} & \multirow{2}{*}{$\begin{array}{l}\text { Length of } \\
\text { River }(\mathrm{km})\end{array}$} & \multirow{2}{*}{$\begin{array}{l}\text { Drainage } \\
\text { Area }\left(\mathrm{km}^{2}\right)\end{array}$} & \multicolumn{2}{|c|}{ Discharge } & \multirow{2}{*}{$\begin{array}{l}\text { Upstream area and } \\
\text { Spring Water Source }\end{array}$} \\
\hline & & & & $\begin{array}{l}\text { Average } \\
\left(\mathrm{m}^{3} / \mathrm{s}\right)\end{array}$ & $\begin{array}{l}\operatorname{Max} \\
\left(\mathrm{m}^{3} / \mathrm{s}\right)\end{array}$ & \\
\hline 1 & Citarum & 269 & 6080 & 171 & 851 & Bandung region \\
\hline 2 & Ciliwung & 117 & 337 & & 500 & $\begin{array}{l}\text { Gede and Pangrango } \\
\text { mount, Puncak }\end{array}$ \\
\hline 3 & Cisadane & 110 & 1100 & & 973 & Salak mount, Bogor \\
\hline
\end{tabular}

Source: compiled from different sources

As described above, there are 13 rivers flowing from the terrestrials to the coastal waters of Jakarta Bay. From those rivers there is one main river called Ciliwung River that have significant impact to the coastal water of Jakarta Bay. In relation to the discharge, water pollution and sediment flux, especially during the last high flood, this river discharge over $500 \mathrm{~m} 3 / \mathrm{s}$ and brought the debris of approximately 11,000 m3 consists of tress and housing materials. In a semi-enclosed coastal water system like the coastal water system of Jakarta bay, natural rivers water input would be accumulated in the bay.

\subsection{Sediment Physical Properties}

Sediment distribution in the estuary consists mostly of black clay and those clays smell bad. In the coastal region and in the dry season, the sediments were black clay and at one sampling site (station S3) the smell of the 
sediment was bad. However, all sampling sites in the coastal areas became bad smell in the rainy season. In the inner bay area, the sediments were greyish green sandy clay with some shell fragments. In the outer bay, the sediments were dominated by greyish green clayey sand with some shell fragments.

The colour of the sediments in the estuaries were black. This may be due to the relatively higher carbon content in that sediments. In this areas the carbon content ranged from 2.21 to $4.34 \%$. The data showed that the carbon content was about two to four times higher than that of the sediments in the inner bay $(1.05-2.19 \%)$ and outer bay (1.15$1.24 \%)$. This also shows that the source of carbon comes from the terrestrial of the Jakarta city. During the rainy season, the black clay sediments were more distributed to the offshore shown by the sediments in the coastal area which were black with bed smell. The effect of river flushing during the rainy season were shown in this phenomena.

\subsection{Carbon/Nitrogen Ratio (C/N)}

$\mathrm{C} / \mathrm{N}$ ratio of the sediments in the dry season ranged from 1 to about 4.2 where in the estuaries (at stations $\mathrm{M} 1, \mathrm{M} 2$ and $\mathrm{M} 4$ ) the ratio were higher compared to the inner and outer bays (figure 2). In this case the $\mathrm{C}$ were total $\mathrm{C}$. These values are consider as low ratios.

\subsection{Total Suspended Solids (TSS)}

Total Suspended Solids (TSS) in dry season showed low concentration between $>10 \mathrm{mg} / \mathrm{l}$ to $<100 \mathrm{mg} / \mathrm{l}$. The highest TSS concentration of approximately $100 \mathrm{mg} / \mathrm{l}$ located in the eastern coast and further eastern coast. High spot of TSS of approximately $50 \mathrm{mg} / \mathrm{l}$ can be observed in the middle to western coast of the bay. Generally, the TSS concentration of surface water to the bottom layer indicate relatively similar pattern (figure 3.). On the other hand, in the rainy season, the TSS concentration showed up to $400 \mathrm{mg} / \mathrm{l}$ in the western coast, and about $300 \mathrm{mg} / \mathrm{l}$ further eastern coast of the bay, however in the inner bay then showed $0-60$ $\mathrm{mg} / \mathrm{l}$ of TSS concentration (figure 4). This phenomena may indicate that higher sediment transport penetration was from the rivers located in the west of Jakarta.
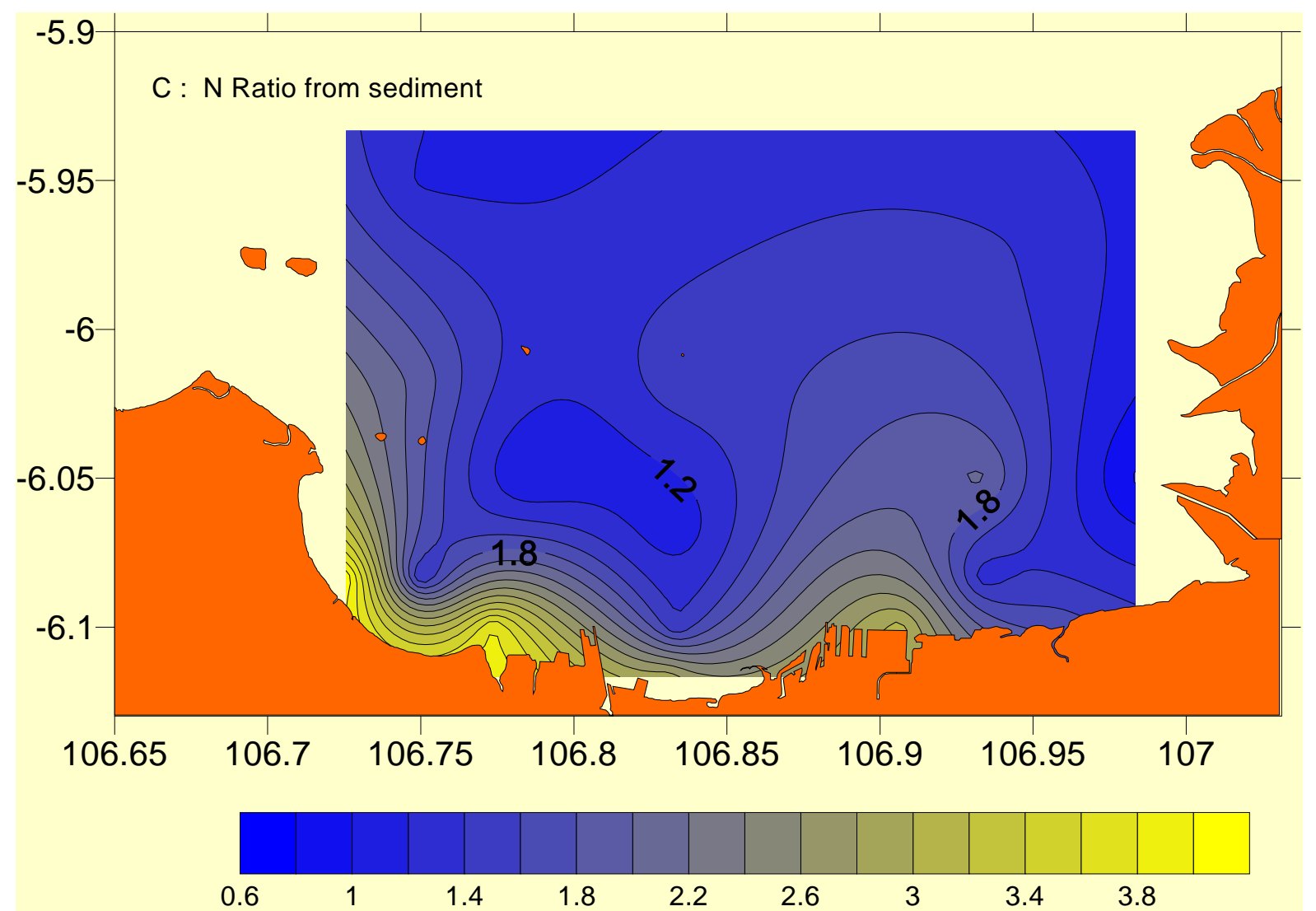

Figure 2. C/N Ratio in the Sediment. 


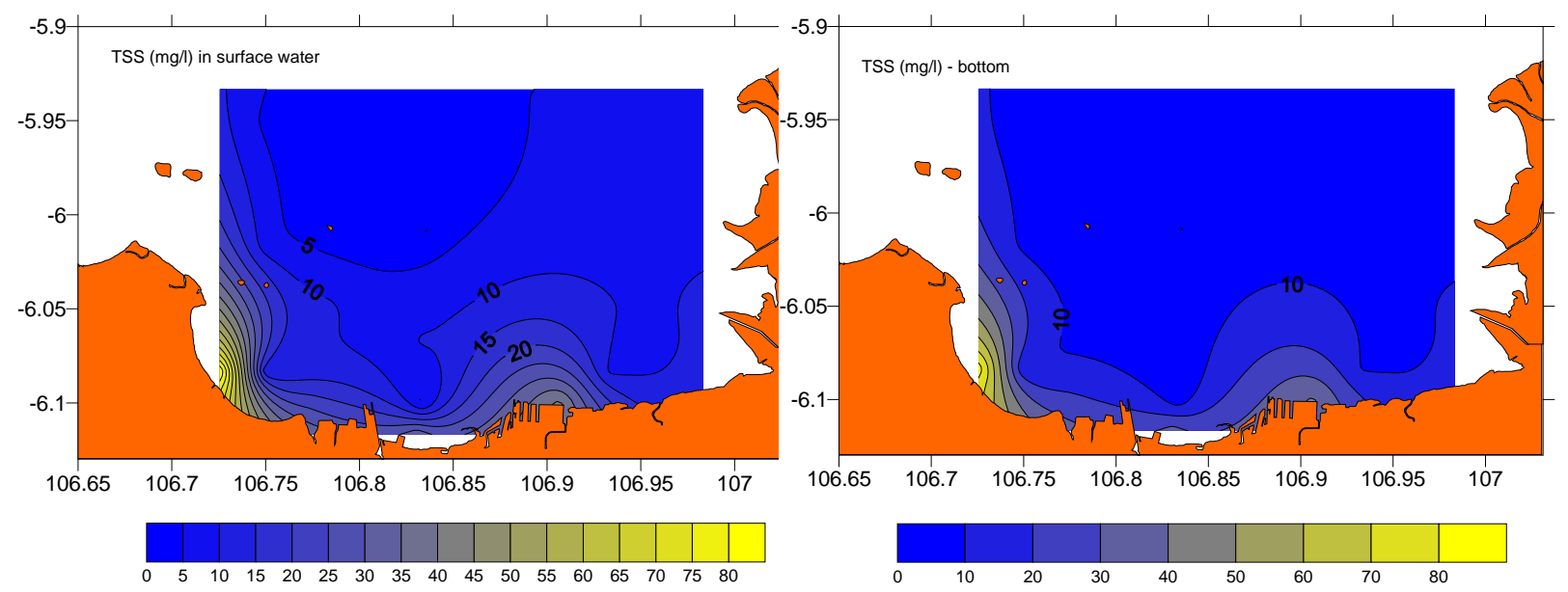

Figure 3. Spatial distribution of TSS in the dry season.

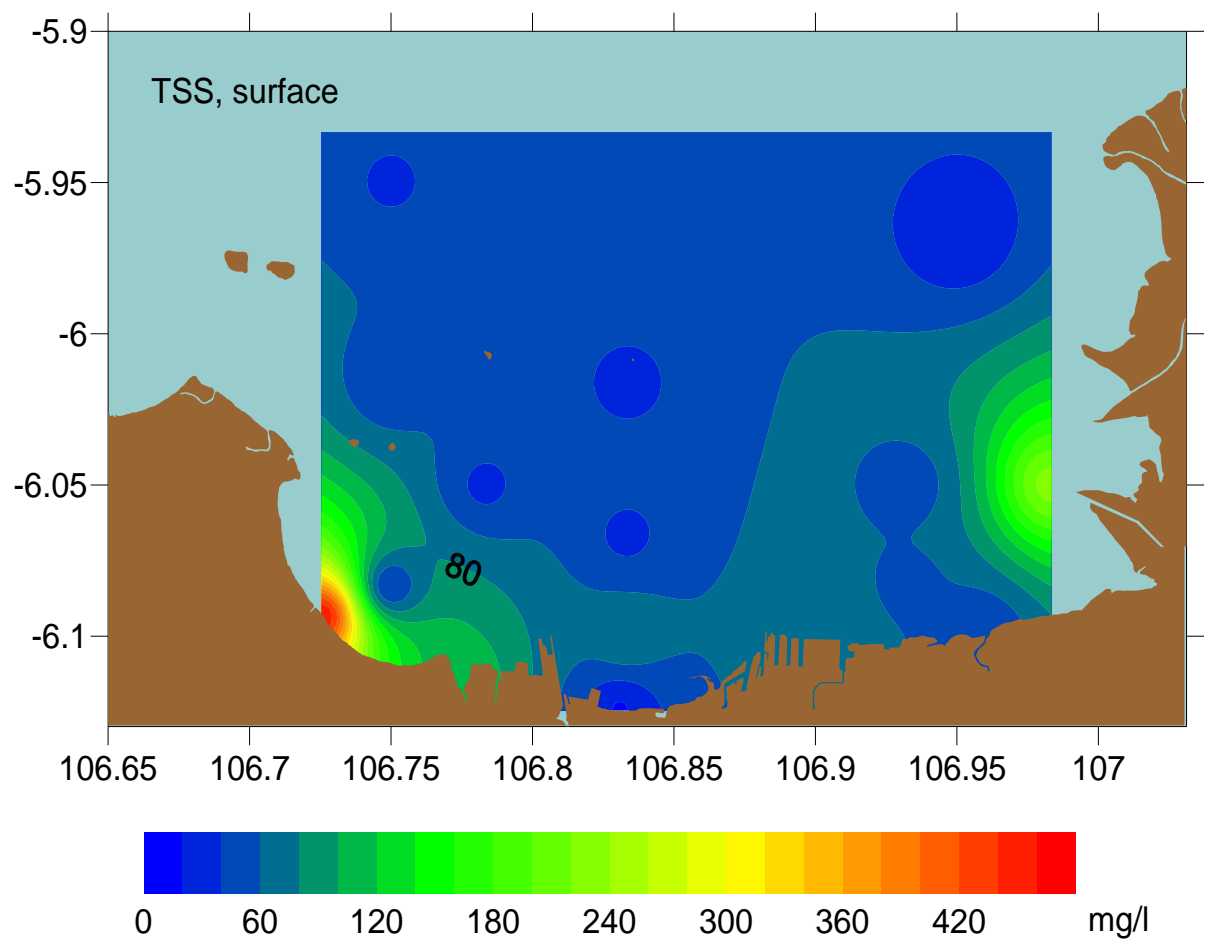

Figure 4. Spatial distribution of TSS in the rainy season.

\subsection{Particulate Organic Carbon (POC)}

Figure 5 shows temporal and spatial variability in $\mathrm{POC}$ concentration in February and May 2007. POC concentrations ranged between $50-650 \mu \mathrm{M}$ and $50-900 \mu \mathrm{M}$, in February and May, respectively. High concentration of POC exists along the coastline or estuaries then decrease toward the sea. POC is distributed widely in February than that in May due to high load from the rivers.
The higher concentration of POC distribution during the rainy season were found in the western and eastern parts of the bay. Referring to the spatial distribution of TSS and Phytoplankton concentrations in the similar location, then this phenomena may show the relationship between $\mathrm{POC}$ and Phytoplankton and TSS concentration distribution.

The high concentration of POC, particularly in the western part of the estuaries and the coastal areas during the dry and rainy seasons most possibly related to the high load of solid waste in this area (see figure 5). 

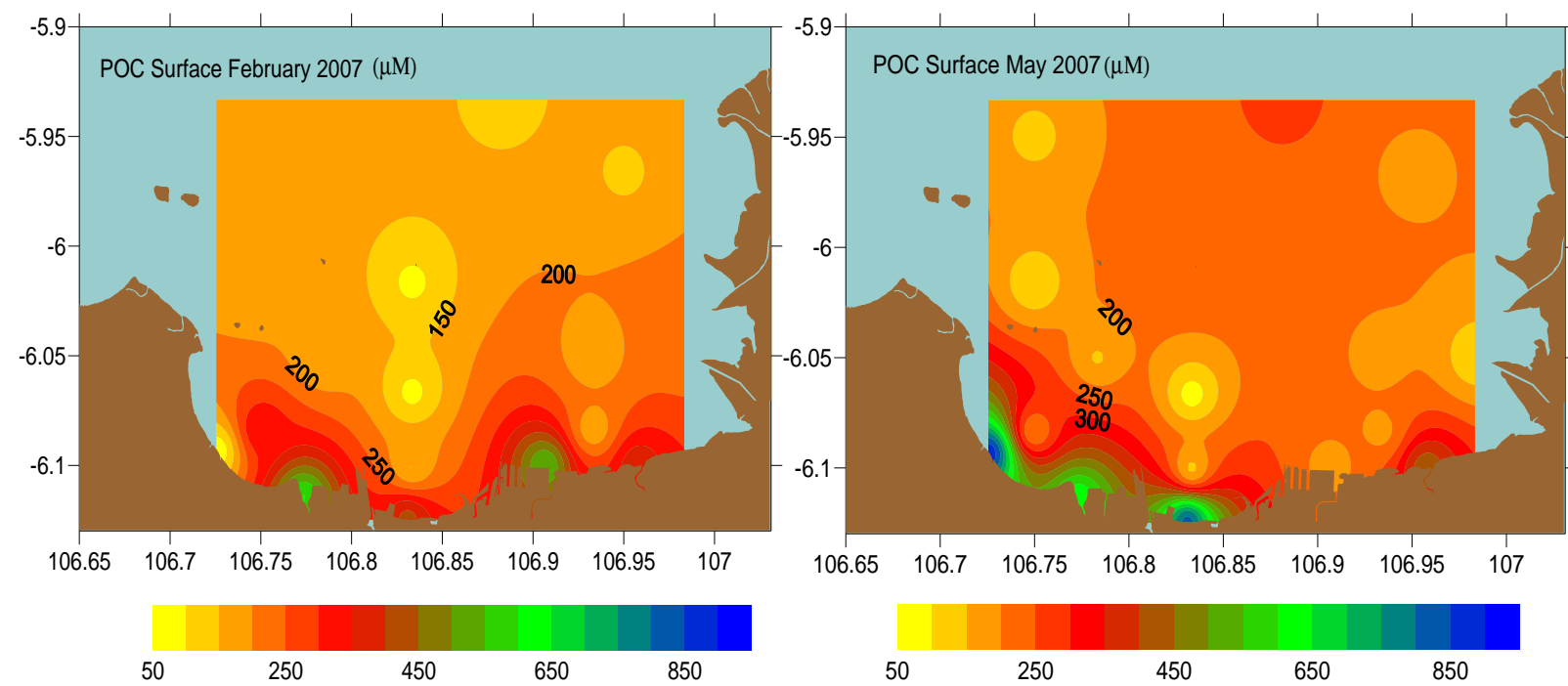

Figure 5. POC concentrations of surface layer during rainy season (left) and dry season (right).

\subsection{Total Organic Carbon (TOC)}

TOC flux from the rivers were shown in figure 6. Even though the average TOC concentrations in February is lower than that in May, but the TOC flux in February is much higher than that in May due to the big difference of river

discharge because, the samples were taken a week after heavy flood in Jakarta Metropolitan Area (February $4-6,2007$ ). Total organic carbon fluxes from the river to the bay in February and May 2007 were $107.6 \mathrm{~T}$ /day C and 42.7 T/day C, respectively.

\section{Seasonal TOC Flux into Jakarta Bay}

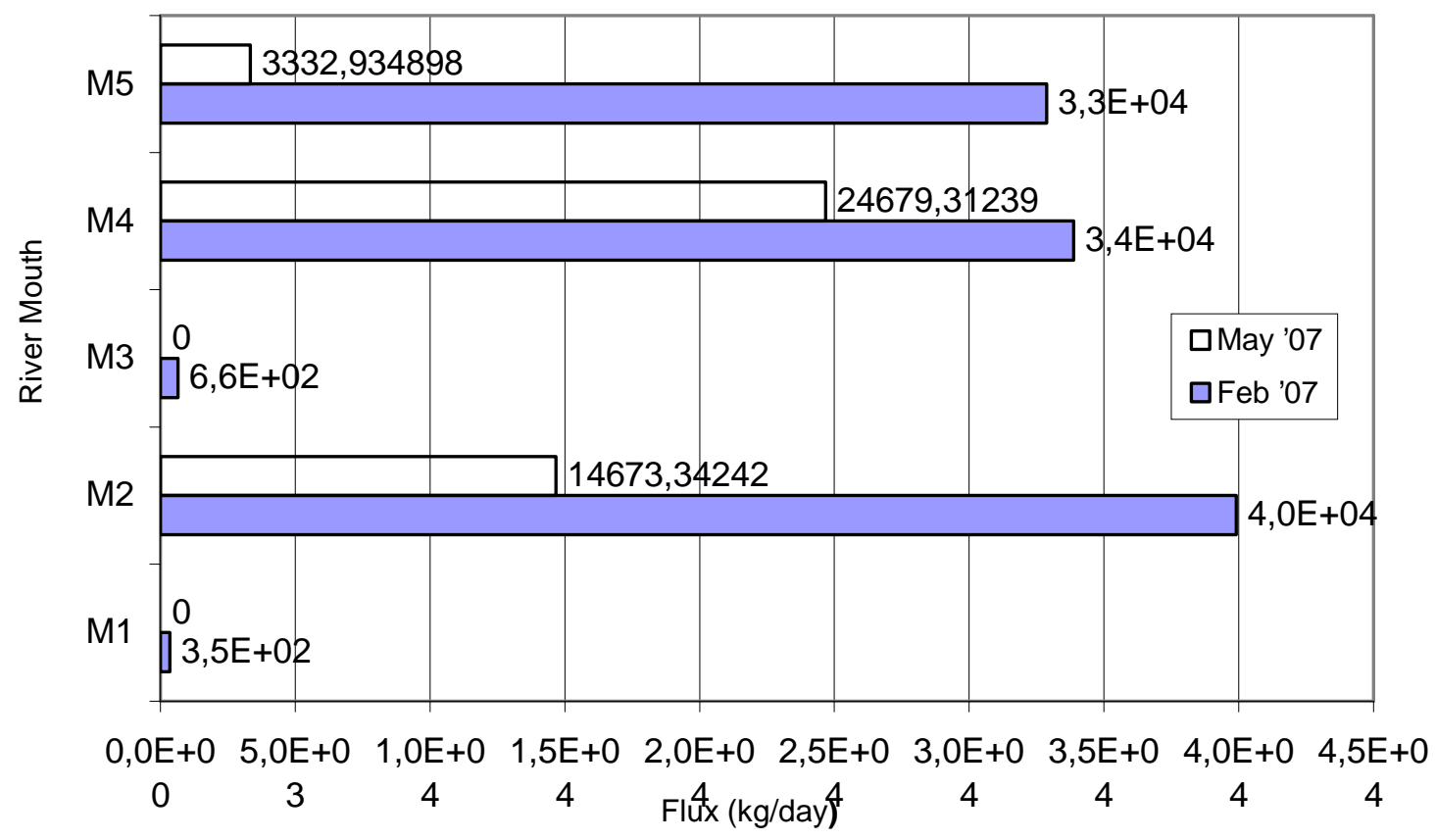

Figure 6. TOC flux into the Jakarta Bay 

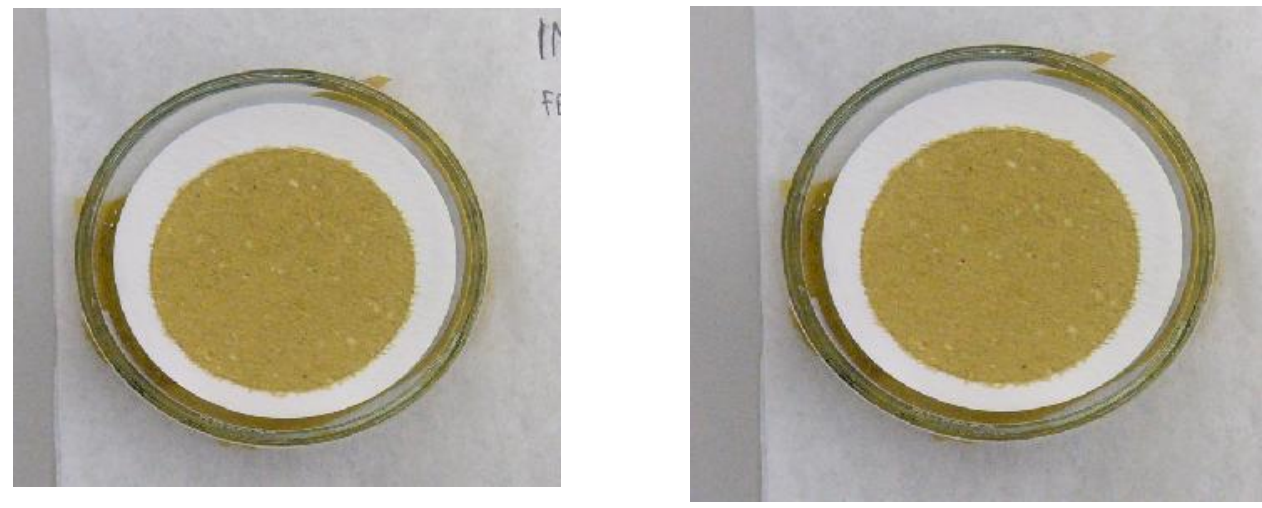

Figure 7. GF/F filtered particulate samples from bottom layer of Inner bay (station IN3, left and station IN4, right) and taken in February 2007
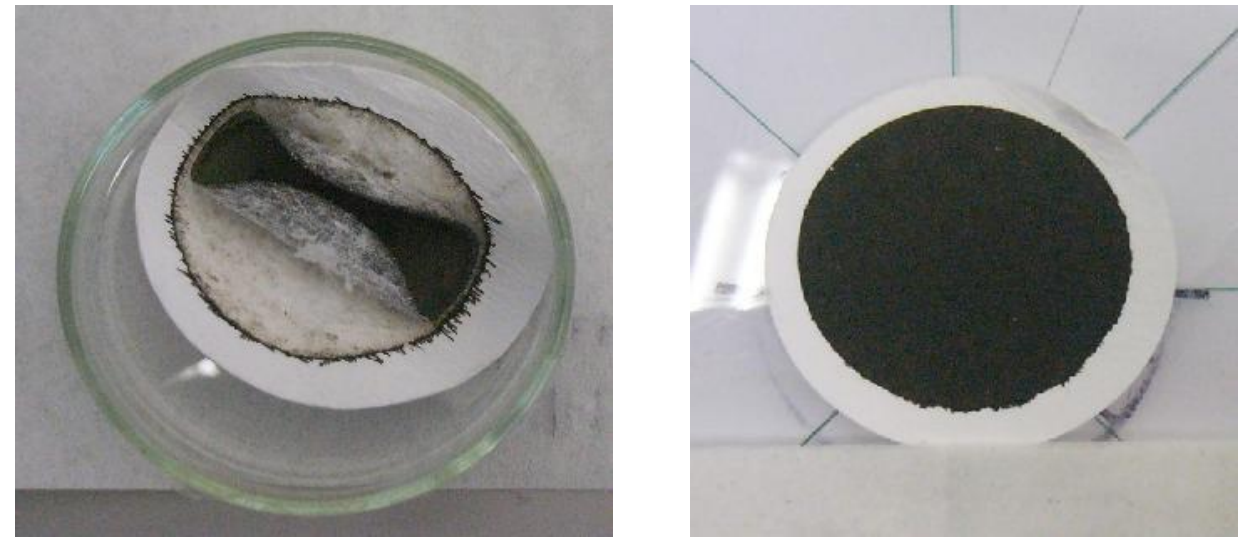

Figure 8. GF/F Filtered samples from station M1 (Muara Kamal) taken in February 2007 (left) and May 2007 (right)
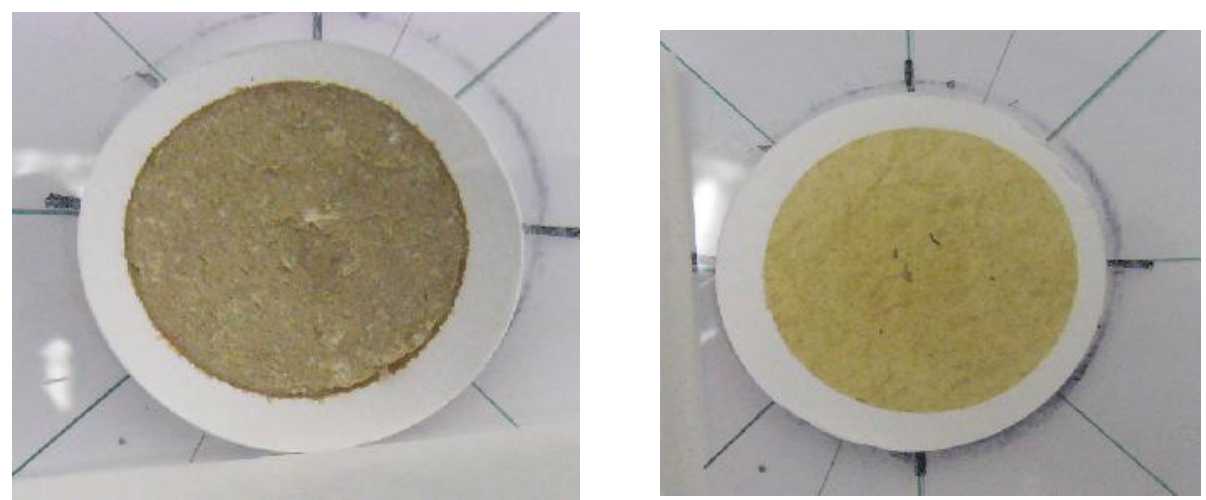

Figure 9. GF/F Filtered samples from station M4 (Sunter Estuary) taken in February 2007 (left) and May 2007 (right) 


\section{CONCLUSIONS}

Sediment distribution in the estuary consists mostly of black clay and those clays bad smell. In the coastal region during the dry season, sediments were black clay and at one sampling site (station S3) the sediment was smelly bad. However, all sampling sites became bad smell in the rainy season. In the inner bay area, the sediments were greyish green sandy clay with some shell fragments. In the outer bay, the sediments were dominated by greyish green clayey sand with some shell fragments.

POC concentrations ranged between 50$650 \mu \mathrm{M}$ and 50-900 $\mu \mathrm{M}$, in February and May, respectively. High concentrations of POC exists along the coastline or estuaries then decreasing toward the sea. POC is distributed widely in February than that in May due to high load from the rivers.

The average TOC concentrations in February is lower than that in May, but the TOC load in February was much higher than that in May due to the big differences of river discharge, because the samples were taken a week after the big flood in Jakarta area (February 4th - 6th, 2007). Total organic carbon fluxes from the river to the bay in February and May 2007 were 107.6 $\mathrm{T}$ /day $\mathrm{C}$ and $42.7 \mathrm{~T}$ /day $\mathrm{C}$, respectively.

\section{ACKNOWLEDGEMENT}

I would like to thank to SARCS Secretariate Taiwan for their financial support for this study which is part of the SARCS Project Report No. 95/01/CW. Special thanks go to ZMT Bremen Germany who facilitated their laboratory for carbon analyses.

\section{REFERENCES}

1. Anonymous, 2002, Environment Status of Indonesia 2002 (in Indonesian), Ministry of Environment, Jakarta.

2. Anonymous, 2002, Environment Status of Jakarta Metropolitan Area 2002 (in Indonesian), Bapedalda DKI Jakarta, Jakarta.

3. Arifin, Z. 2004. Trend of Coastal Pollution in Jakarta Bay: It's Implication to Fishery and Recreational Activitie, Ed. R. Rachmawati et al. Proceeding on Bilateral Workshop on Coastal Resources Exploration and Conservation Indo-German Experience, Denpasar.

4. Baum, Antje, Tim Rixen, Joko Samiaji, 2007, Relevance of Peat Draining Rivers In Central Sumatra for the Riverine Input of Dissolved Organic Carbon Into The Ocean, Estuarine Coastal and Shelf Science, 73, pp 563 - 570.
5. Chen. C.T.A, 2004, Exchange of Carbon in the Coastal Seas, in the Global Carbon Cycle: Integrating Humans, Climate, and the Nature World, eds. C.B. Field and M.R. Raupach, SCOPE 62, Island Press, Washington DC.

6. Crossland, J.C., Kremer, H. H., Lindeboom, H.J., Crossland, J.M., Le Tissier, M. D. , 2005, Coastal Fluxes in the Anthropocene, Springer, Berlin.

7. Damar, A., 2003. Effects of Enrichment on Nutrient Dynamics, Phytoplankton Dynamics and Productivity in Indonesian Tropical Waters: A Comparison between Jakarta Bay, Lampung Bay and Semangka Bay, Dissertation, Christian-Albrecht University of Kiel.

8. Global Carbon Project, 2003, Science Framework and Implementation, Earth System Science Partnership/ESSP (IGBP,IHDP, WCRP, and DIVERSITAS) Report No. 1: Global Carbon Project Report No. 169 pp, Canberra.

9. Gordon, D.C. Jr, Boudreau, P.R., Mann, K.H., Ong, K.H., Silvert, W.L., Smith, S.V., Watayakorn, G., Wullf F., and Yanagi, T., 1996. LOICZ Biogeochemical Modeling Guideline, LOICZ, Texel, The Netherlands, $96 \mathrm{pp}$.

10. Kompas Daily News, 23rd January 2005.

11. Maimun, F., 1984, Meteorological Data for The Jakarta - Bogor Area, German Hydrogeological Advisory Group in Indonesia - CTA 40, Working Paper 75, Drectorate of Environmental Geology, Bandung, 24 pp.

12. Smith, S.V., V. Dupra, J.I. Marshall Crossland and C.J. Crossland, 2000. Estuarine System of the South China Sea Region: Carbon, Nitrogen and Phosphorus Fluxes, LOICZ Report \& Studies No. 14, ii+156 pages, LOICZ IPO, Texel, The Netherlands.

13. Soeharto, H., 1996. Flood Operational Control of Jakarta City, Seminar on Jakarta and Its Flooding, IKANED, Jakarta

14. Susanna, N., Yanagi, T., 2002. Lower Trophic Level Ecosystem in Jakarta Bay, Indonesia. Lamer vol. 40, pp 161-170, Tokyo.

15. Yanagi, Tetsuo, 1993, A Carbon Budget of Tokyo Bay, Journal of Oceanography, Vol. 49, pp. 249 to 256.

16. Yanagi,T., Saino, T., Shinichi., U., 1993, A Carbon Budget in Tokyo Bay, Journal of Oceanography Vol. 49, pp.249-256. Tokyo. 